\title{
Faktor-faktor Penyebab Terjadinya Persalinan Dengan Tindakan Sectio Caesarea di Ruang Bersalin Rumah Sakit Tingkat IV Wira Bhakti Mataram
}

\author{
Asri Daniyati ${ }^{1 *}$ dan Shohipatul Mawaddah ${ }^{1}$ \\ ${ }^{1}$ Jurusan Ilmu Kebidanan, Universitas Nahdlatul Wathan, Mataram, Indonesia \\ *Email : dzakyzenna@gmail.com
}

\begin{abstract}
Abstrak : Berdasarkan data Rumah sakit Tingkat IV Wira Bhakti Mataram angka persalinan dengan Sectio Caesara cukup tinggi dimana menunjukan jumlah persalinan Sectio Caesara pada tahun 2016 dari bulan januarijuli sebanyak 238 orang dan pada tahun 2021 dari bulan januari sampai maret sebanyak 94 orang. Penelitian ini bertujuan untuk mengetahui faktor penyebab persalinan dengan tindakan sectio caesarea.Jenis penelitian yang di gunakan dalam penelitian ini yaitu penelitian deskritif. Populasi penelitian ini adalah ibu yang mengalami persalinan secara Sectio Caesara yaitu sebanyak 94 orang, sedangkan sampel dalam penelitian ini sebanyak 94 orang dimana teknik pengambilan sampel menggunakan total populasi. Penelitian ini di lakukan pada bulan agustus tahun 2021, mengumpulkan data skunder, analisa yang di gunakan dalam penelitian ini adalah analisa univariat. Hasil penelitian ini menunjukan dari 94 ibu yang mengalami persalinan Sectio Caesara adapun faktor umur yang paling tinggi yaitu pada usia 20-35 tahun sebanyak 73orang (77,6\%), faktor pekerjaan yang paling tinggi pada pekerjaan IRT sebanayk 54 orang (57,45\%), faktor penyebab yang paling tinggi yaitu faktor ibu sebanyak 74 orang $(78,72 \%)$ penyebab Sectio Caesara tertinggi dari faktor ibu yaitu riwayat Sectio Caesara sebanyak 28 orang $(37,84 \%)$, dari faktor janin kejadian yang paling tinggi menyebabkan persalinan Sectio Caesara yaitu letak lintang sebanyak 10 orang (50\%) Di dasarkan pada instusi pelayanan kesehatan hendaknya meningkatkan kualitas pelayanan khususnya dalam pemberian peran aduction untuk ibu dan keluarga di antranya adalah penyuluhan kesehatan tentang persalinan yang lebih awal agar terhindar dari kemungkinan komplikasi yang dapat terjadi. .
\end{abstract}

Kata kunci : Sectio Caesara, Penyebab, Tindakan

\section{Pendahuluan}

Setiap perempuan menginginkan persalinannya berjalan lancar dan dapat melahirkan bayi dengan sempurna. Persalinan bisa saja berjalan secara normal, namun tidak jarang proses persalinan mengalami hambatan dan harus dilakukan melalui operasi. Hal ini berarti janin dan ibu dalam keadaan gawat darurat dan hanya dapat diselamatkan jika persalinan dilakukan dengan jalan operasi.

Persalinan pervaginam dianggap sebagai proses persalinan yang sulit dan cenderung berbahaya bagi calon ibu dan bayinya, sehingga operasi sesar meskipun merupakan metode persalinan dengan melakukan pembedahan besar pada perut cenderung disukai daripada persalinan melalui jalan lahir (pervaginam). Meskipun pada masa lalu Sectio Caesarea (SC) masih menjadi hal yang menakutkan namun dengan berkembangnya kecanggihan bidang ilmu kedokteran kebidanan pandangan tersebut mulai bergeser. Kini persalinan melalui operasi sesar kerap menjadi alternatif pilihan persalinan. Di China tingkat operasi sesar meningkat drastis dari 3,4 persen tahun 1988 mencapai 39,3 persen tahun 2008, bahkan data WHO Global Survey on Maternal and Perinatal Health 2008 menunjukkan 46,2 persen. Meskipun tarif operasi sesar meningkat lebih tiga kali lipat di semua wilayah di China, namun peningkatan operasi sesar tetap terjadi. Bahkan di kalangan perempuan perkotaan 64,1 persen dari seluruh kelahiran dengan sesar.

World Health Organization(WHO) menetapkan standar rata-rata persalinan operasi sesar di sebuah negara adalah sekitar 5- 15 persen per 1000 kelahiran di dunia. Menurut WHO, peningkatan persalinan dengan operasi sesar di seluruh negara terjadi semenjak tahun 2007- 2008 yaitu 110.000 per kelahiran diseluruh Asia.

Di Indonesia sendiri, angka kejadian operasi sesar juga terus meningkat baik di rumah sakit pemerintah maupun di rumah sakit swasta. Menurut Data Survei Demografi dan Kesehatan Indonesia (SDKI) menunjukkan terjadi kecenderungan peningkatan operasi sesar di Indonesia dari tahun 1991 sampai tahun 2007 yaitu 1,3-6,8 persen. Persalinan sesar di kota jauh lebih tinggi dibandingkan di desa yaitu 11 persen dibandingkan 3,9 persen.

Hasil Riskesdas tahun 2013 menunjukkan kelahiran dengan metode operasi sesar sebesar 9,8 persen dari total 49.603 kelahiran sepanjang tahun 2010 sampai dengan 2013, dengan proporsi tertinggi di DKI Jakarta $(19,9 \%)$ dan terendah di Sulawesi Tenggara (3,3\%). Secara umum pola persalinan melalui operasi sesar menurut 
karakteristik menunjukkan proporsi tertinggi pada kuintil indeks kepemilikan teratas $(18,9 \%)$, tinggal di perkotaan $(13,8 \%)$, pekerjaan sebagai pegawai $(20,9 \%)$ dan pendidikan tinggi/lulus PT $(25,1 \%) .8$ Beberapa penelitian terdahulu mengenai pentingnya menganalisa faktor-faktor yang mempengaruhi pilihan ibu untuk melakukan persalinan SC antara lain penelitian yang dilakukan oleh RA MendozaSassi di Brasil pada tahun 2010 yang memperlihatkan pentingnya menganalisa faktorfaktor risiko untuk persalinan sesar menggunakan kategori khusus yang disediakan oleh penyedia layanan kesehatan untuk mengantisipasi meningkatnya rasio persalinan sesar tanpa indikasi medis di Brasil.

\section{Metode Peneltian}

Jenis penelitian ini adalah penelitian deskriptif Metode deskriptif adalah suatu metode penelitian yang menggambarkan variabel-variabel yang diteliti tanpa menganalisa hubungan antara variabel. Dalam penelitian ini di gunakan teknik total sampling yaitu teknik pengambialan sample dimana jumlah sampel sama dengan populasi (sugiyono, 2011)

\section{Hasil dan Pembahasan}

\section{Hasil}

3.1 Identifikasi Karakteristik Ibu Yang Mengalami Persalinan Tindakan Meliputi Umur dan Pekerjaan di Rumah Sakit Tingkat IV wira Bhakti Mataram Tahun 2021.

\section{A. Umur}

Berdasarkan pengolahan data sekunder terhadap 94 sampel penelitian, diperoleh hasil menurut umur ibu yang dapat dilihat pada tabel sebagai berikut : Tabel 5.3 Distribusi frekuensi Karakteristik Ibu Berdasarkan Umur di Rumah Sakit Tingkat IV wira Bhakti Mataram Tahun 2021.

Tabel 3.1 Identifikasi Karakteristik Ibu Yang Melakukan Persalinan Sectio Caesarea berdasarkan Umur di Rumah Sakit Tingkat IV Wira Bhakti Mataram Tahun 2021.

\begin{tabular}{|c|c|c|c|}
\hline No. & $\begin{array}{c}\text { Kategori } \\
\text { Umur }\end{array}$ & $\mathbf{N}$ & $\boldsymbol{\%}$ \\
\hline 1 & $<20$ tahun & 1 & 1.0 \\
\hline 2 & $20-35$ tahun & 73 & 77,6 \\
\hline 3 & $>35$ tahun & 20 & 21 \\
\hline \multicolumn{2}{|c|}{ Jumlah } & 94 & 100 \\
\hline
\end{tabular}

Berdasarkan Tabel 5.3 di atas dapat di ketahui bahwa umur ibu yang paling banyak adalah 20-35 tahun yaitu sebanyak $73 \mathrm{ibu}(77,6 \%)$, dan usia ibu yang paling sedikit adalah umur $<20$ tahun yaitu sebanyak $1 \mathrm{ibu}(1,0 \%)$.

\section{B. Pekerjaan}

Berdasarkan pengolahan data sekunder terhadap 94 sampel penelitian, diperoleh hasil menurut pekerjaan yang dapat dilihat pada tabel sebagai berikut :

Tabel 3.2 Karakteristik Ibu Berdasarkan Paekerjaan di Rumah Sakit Tingkat IV Wira Bhakti Mataram Tahun 2020.

\begin{tabular}{|c|c|c|c|}
\hline No & $\begin{array}{c}\text { Jenis } \\
\text { Pekerjaan }\end{array}$ & N & $\%$ \\
\hline 1 & PNS/Honorer & 18 & 19,15 \\
\hline 2 & Wiraswasta & 21 & 22,34 \\
\hline 3 & Buruh & 1 & 1,06 \\
\hline 4 & & 54 & 57,45 \\
\hline & Jumlah & 94 & 100 \\
\hline
\end{tabular}

Dari Tabel 3.2 di atas dapat diketahui bahwa pekerjaan ibu yang paling banyak adalah IRT yaitu sebanyak 54 orang $(57,45 \%)$ dan pekerjaan ibu yang paling sedikit adalah buruh yaitu 1 orang $(1,06 \%)$.

\subsection{Identifikasi Persalinan Dengan Tindakan Seksio Sesarea Berdasarkan faktor Ibu dan Janin di Rumah Sakit Tingkat IV wira Bhakti Mataram Tahun 2021}

Berdasarkan data yang telah dikumpulkan dari Rekam Medik Rumah Sakit Tingkat IV wira Bhakti Mataram dari bulan januari sampai maret Tahun 2021.

Tabel 3.3 Identifikasi Persalinan Dengan Tindakan Seksio Sesarea berdasarkan faktor Ibu di Rumah Sakit Tingkat IV wira Bhakti Mataram Tahun 2021

\begin{tabular}{|c|c|c|}
\hline $\begin{array}{c}\text { Faktor - faktor } \\
\text { penyebab SC }\end{array}$ & $\begin{array}{c}\text { Frekuensi } \\
\text { (n) }\end{array}$ & $\begin{array}{c}\text { Persentase } \\
(\%)\end{array}$ \\
\hline a. KPD & 7 & 9,46 \\
\hline b. CPD & 15 & 20,27 \\
\hline c. PEB & 4 & 5,40 \\
\hline d. Plasenta previa & 0 & 0 \\
\hline e. Riwayat SC & 28 & 37,84 \\
\hline f. Partus lama & 6 & 8,11 \\
\hline g. Solusio plasenta & 0 & 0 \\
\hline h. Oligohidramnion & 14 & 18,92 \\
\hline Jumlah & 74 & 100 \\
\hline
\end{tabular}

Berdasarkan Tabel 3.3 di atas menunjukkan bahwa pada persalinan dengan tindakan seksio sesarea pada faktor ibu yang lebih banyak adalah faktor riwayat SC sebanyak 28 ibu $(37,84 \%)$ dan yang paling sedikit pada faktor PEB sebanyak $4 \mathrm{ibu}$ $(5,40 \%)$. 
Tabel 3.4 Identifikasi Persalinan Dengan Tindakan Seksio Sesarea berdasarkan faktor Ibu di Rumah Sakit Tingkat IV wira Bhakti Mataram Tahun 2021

\begin{tabular}{|c|c|c|}
\hline $\begin{array}{c}\text { Faktor - faktor } \\
\text { penyebab SC }\end{array}$ & $\begin{array}{l}\text { Frekuensi } \\
\text { (n) }\end{array}$ & $\begin{array}{c}\text { Persentase } \\
(\%)\end{array}$ \\
\hline a. Janin Besar & 4 & 20 \\
\hline b. Gawat Janin & 1 & 5 \\
\hline c. Letak lintang & 10 & 50 \\
\hline d. Letak sungsang & 5 & 25 \\
\hline e. Gemeli & 0 & 0 \\
\hline Jumlah & 20 & 100 \\
\hline
\end{tabular}

Berdasarkan Tabel 5.6 di atas menunjukkan bahwa pada persalinan dengan tindakan seksio sesarea pada foktor janin yang lebih banyak terdapat pada foktor letak lintang sebanyak 10 janin (50\%) dan yang paling sedikit faktor dengan gawat janin sebanyak 1 janin $(1,0 \%)$.

\section{Pembahasan}

\section{A. Umur}

Berdasarkan Tabel 5.6 dapat dilihat bahwa umur ibu yang bersalin dengan tindakan seksio sesarea terbanyak berasal dari golongan umur yang tidak berisiko yakni antara 20-35 tahun sebesar $77,6 \%$ dan terkecil berasal dari golongan umur $<20$ tahun yaitu sebesar $1,0 \%$. Hal ini bisa dikarenakan oleh ibu yang datang bersalin ke RSAD Wirabhakti Mataram sebagian besar berumur 20-35 tahun. Dimana, pada sebagian besar ibu tersebut mengalami komplikasi kehamilan sehingga pengakhiran persalinan dilakukan dengan tindakan seksio sesarea.

Kejadian seksio sesarea pada ibu yang berusia $<20$ tahun antara lain berhubungan dengan kematangan organ reproduksi termasuk panggul di dalamnya. Dimana pertumbuhan panggul yang belum sempurna ibu dengan usia $<20$ tahun lebih rentan menderita panggul sempit yang merupakan indikasi untuk dilakukannya seksio sesarea (Cunningham,2005)

Sedangkan ibu dengan usia $>35$ tahun lebih rentan terjadi komplikasi persalinan seperti preeklampsia dan hipertensi sehingga risiko untuk persalinan tindakan secara seksio sesarea juga tinggi. Berdasarkan penelitian di RS Cipto Mangunkusumo, frekuensi plasenta previa dua kali lebih besar pada primigravida dengan umur $>35$ tahun dibandingkan dengan primigravida dengan umur $<25$ tahun. Sehingga dapat disimpulkan risiko untuk terjadinya tindakan seksio sesarea pada ibu dengan usia >35 tahun lebih besar dibandingkan dengan ibu usia 20-35 tahun (Prawirohardjo, 2009).

Menurut penelitian Fitri Aryuni Esta, angka kejadian persalinan dengan tindakan sectio caesarea pada usia 20-35 tahun sebanyak $(62,9 \%)$, dan pada usi ( $<20$ tahun $>35$ tahun) sebanyak $(37,1)$ di RSUD Rantauprat tahun 2017 Sebanding dengan penelitian Desi Martianing Astuti angka kejadian persalinan dengan tindakan sectio caesarea pada usia 20-35 tahun sebanyak $(70,8 \%)$, dan pada usi ( $<20$ tahun $>35$ tahun) sebanyak $(29,2 \%)$ di RSU PKU Muhamddiyah kota Yogyakarta tahun 2016 yang menyatakan ibu yang melakukan persalina secara sectio caesarea lebih banyak yang umurnya di antara 20-35 tahun

\section{B. Pekerjaan}

Berdasarkan tabel 3.2 dapat dilihat bahwa sebagian besar hasil penelitian menunjukkan bahwa proporsi ibu yang mengalami persalinan dengan seksio sesarea tertinggi $57,45 \%$ ibu dengan pekerjaan sebagai ibu rumah tangga dan proporsi terendah $1,06 \%$ dengan pekerjaan sebagai Buruh. Hal ini bukan merupakan indikasi keterkaitan pekerjaan dengan seksio sesarea atau tidak ada hubungan seksio sesarea dengan pekerjaan, namun hanya menunjukkan jumlah kunjungan ibu yang mengalami persalinan dengan seksio sesarea yang mayoritas sebagai ibu rumah tangga.

Hasil penelitian Dodo Khodijah pada tahun 2019 di Rumah Sakit Tk IV.01.07.001 Kesdam I/BB Pematangsianta ini menemukan mayoritas responden bekerja sebagai Wiraswasta $(44,3 \%)$ paling rendah pada PNS (12,2). SC merupakan jenis persalinan dimana ibu dapat menentukan tanggal dan waktu persalinan. Dengan dilakukan SC, ibu yang bekerja dapat lebih mudah mengatur jadwal kelahiran yang dapat disesuaikan dengan pekerjaan (Jovany, 2012). Pada penelitian ini terlihat tidak terdapat hubungan yang signifikan. Hasil penelitian ini berbeda dengan hasilpenelitian Ginting tahun 2002 di Rumah Sakit Umum Herna bahwa proporsi ibu yang mengalami persalinan dengan SC tertinggi 57,7\% dengan pekerjaan Ibu Rumah Tangga. Namun juga bukan berperan penting dalam faktor penyebab persalinan SC, tetapi karena ada faktor lain yang cukup kuat untuk dilakukannya tindak persalinan SC (Trivonia, dkk 2011).

Pekerjaan merupakan suatu kegiatan atau aktifitas seseorang untuk memperoleh penghasilan guna memenuhi kebutuhan hidup sehari-hari. Pekerjaan dapat menggambarkan tingkat kehidupan seseorang karena dapat mempengaruhi aspek kehidupan seseorang termasuk pemeliharaan kesehatan. Dinyatakan bahwa jenis pekerjaan dapat berperan dalam pengetahuan. (Notoatmodjo, 2007).

\section{a. Faktor ibu}

Faktor penyebab persalina section caesarea dari faktor ibu dengan identifikasi KPD sebanyak 7 Orang $(9,46 \%)$, CPD sebanyak 15 orang $(20,27 \%)$, PEB sebanyak 4 orang $(5,40 \%)$, plasenta previa sebanyak 0 orang $(0 \%)$, riwayat Sc sebanyak 28 orang $(37,84 \%)$, partus lama sebnyak 6 orang $(8,11 \%)$, solusio plasenta sebanyak 0 orang $(0 \%)$, oligohidramnion sebanyak 14 orang $(18,92 \%)$, dari hasil penelitian yang di ambil pada rekam medik pada bulan januari samapai maret hatun 2020 dengan persalinan section caesarea dari faktor ibu sebagaian besar indikasi section caesarea ulang yaitu sebanyak 28 orang $(37,84 \%)$. 
Sebagian besar yang melakukan persalinan dengan section caesarea yaitu ibu dengan riwayat section caesarea sebelumnya hal ini dilakukan untuk mencegah terjadinya resiko atau komplikasi yang dapat membahayakan iu dan janin. Hal ini sesuai dengan teori yang menyebutkan bahwa pada ibu yang sebelumnya yang mengalami persalinan dengan section caesarea meningkatkan resiko robekan dinding rahim bila mereka mencoba persalinan pervaginam pada kehamilan berikutnya. (IKABI 2010).

Menurut penelitian Ruri Maiseptya Sari, angka kejadian persalinan dengan tindakan sectio caesarea dengan indikasi oligohidramnion di Rumah Sakit DKT Bangkulu tahun 2017 hasil penelitian ini menunjukkan jumlah oligohidramnion sebesar $1,35 \%$.

\section{b. Faktor Janin}

Faktor penyebab persalinan section caesarea dari factor janin dengan indikasi janin besar sebanyak 4 orang (20\%), gawat janin sebanyak 1 orang $(5 \%)$, letak lintang sebanyak 10 orang $(50 \%)$, letak sungsang sebanyak 5 orang $(25 \%)$, gemeli sebanyak 0 orang $(0 \%)$. Dari hasil penelitian di dapatkan bahwa ibu dengan persalinan section caesarea dari faktor janin sebagian besar indikasi letak lintang yaitu sebanayak 10 orang $(50 \%)$.

Menurut penelitian Sadiman dkk (2009), yang menyatakan terdapat hubungan yang signifikan antara letak lintang dengan persalinan seksio sesarea. Dalam penelitian ini meskipun secara statistik tidak didapatkan hubungan yang signifikan tetapi dari persalinan dengan letak lintang, seluruhnya menjalani persalinan dengan seksio sesarea, hal ini sejalan dengan Prawiroharjo (2009) dalam buku acuan nasional pelayanan kesehatan maternal dan neonatal menyebutkan bahwa letak lintang menjadi indikasi janin untuk dilakukan seksio sesarea Letak lintang tidak akan dapat lahir secara spontan, bila tidak dikoreksiakan menyebabkan kemacetan persalinan yang berujung pada kematian janin bahkan ibunya, oleh karena itu seksio sesarea elektif merupakan indikasi untukmenyelamatkan ibu maupun janinnya.

Faktor penyebab persalinan section caesarea dari faktor janin dengan indikasi janin besar sebanyak 1 orang $(5 \%)$.

Mekanisme persalinan sungsang hampir sama dengan letak kepala, hanyadisini yang memasuki pintu atas panggul adalah bokong. Persalinan berlangsung lebih lama karena karena bokong lebih lembek bila dibandingkan kepala, jadi kurang kuat menekan sehingga pembukaan serviks lebih lama. Letak sungsang tidak harus dilakukan dengan seksio sesarea, petugas kesehatan diharapkan mengutamakan persalinan normal terlebih dahulu, bila persyaratan persalinan normal tidak terpenuhi maka jalan terbaik adalah denga persalinan seksiosesarea untuk menghindari cedera pada bayi. (Muhtar, 2015)

Komplikasi persalinan letak sungsang meliputi morbiditas dan mortalitas bayi yang tinggi, dapat menurunkan IQ bayi. Komplikasi segera pada ibu meliputi perdarahan, trauma persalinan, infeksi. Sedangkan pada janin meliputi perdarahan (intracranial, aspirasi air ketuban dan aspiksia). Kematian bayi dapat terjadi karena asfiksia berat, perdarahan intra cranial daninfeksi otak. Bila bayi berhasil ditolong, komplikasinya meliputi fraktur leherdan persendiannya, gangguan pusat vital janin pada medulla oblongata dan dapatmenimbulkan cacat seumur hidup. Kegagalan persalinan kepala janin dapat diduga sebelumnya sekalipun badannya dapat lahir biasa. Sikap bidan dalam menghadapi persalinan dengan letak sungsang adalah bila masih ada kemungkinan untuk mengirim pasien ke rumah sakit yang mampu melakukan pertolongan yang lebih baik. Bila sangat terpaksa dengan bokong sudah didasar panggul maka lakukan upaya persalinan dengan Bracht. Kini kecenderungan untuk melakukan operasi pada semua letak sungsang untuk dapat mencapai well born babydanwell health mother (Manuaba, 2008)

Menurut penelitian Fitri Aryuni Esta, angka kejadian persalinan dengan tindakan sectio caesarea dengan indikasi letak sungsang di RSUD Rrantauprapat tahun 2017 rata-rata sebesar 9,3\%.

Menurut penelitian Ruri Maiseptya Sari, angka kejadian persalinan dengan tindakan sectio caesarea dengan indikasi letak sungsang di Rumah Sakit DKT Bangkulu tahun 2017 hasil penelitian ini menunjukkan jumlah letak sungsang sebesar 14,2\% lebih rendah dari hasil penelitian yang dilakukan Mindarsih (2015) di RS Panembahan Senopati Bantul yang menunjukkan proporsi letak sungsang pada persalinan sectio caesarea sebesar 22,11\%. Namun relatif sama dengan penelitian di RSU Dr. Soedarso Pontianak pada tahun 2010 yang menunjukkan proporsi letak sungsang dalam tindakan sectio caesareasebesar $13,77 \%$

\section{Kesimpulan}

Berdasarkan hasil penelitian dan pembahasan yang diuraikan pada bab sebelumnya tentang Faktor-faktor penyebab Terjadinya persalinan dengan tindakan section caesarea di Ruang Bersalin Rumah Sakit Tingkat IV Wira Bhakti Mataram serta merujuk kepada tujuan khusus dari penelitian peneliti dapat menarik kesimpulan sebagai berikut :

1. Dari 94 ibu yang melakukan persalinan dengan tindakan sectio caesarea yang di teliti pada faktor usia yang paling tinggi pada usia 20-35 tahun sebanyak 73 orang $(77,6 \%)$

2. Dari 94 ibu yang melakukan persalinan dengan tindakan sectio caesarea yang di teliti pada faktor pekerjaan yang paling tinggi pada pekerjaan IRT sebanyak 54 orang $(57,45 \%)$.

3. Dari 94 ibu yang melakukan persalinan dengan tindakan sectio caesarea yang di teliti pada faktor ibu dengan indikasi riwayat SC sebanyak 28 orang $(37,84 \%)$

4. Dari $94 \mathrm{ibu}$ yang melakukan persalinan dengan tindakan sectio caesarea yang di teliti pada 
faktor janin dengan indikasi letak lintang sebanyak 10 orang $(50 \%)$

\section{Daftar Pustaka}

Ann Alpers. 2006. Buku Ajar Pediatri Rudolph. Jakarta: EGC

Caroline Hutomo. 2008. Terapi Pre-eklampsia, CDK. Vol 35. No. 1, Januari-Februari 2008

Christine Handerson. 2005. Buku Ajar KonsepKebidanan. Jakarta: EGC

Departemen Kesehatan RI, 2015. Pedoman Pemantauan Wilayah Setempat Kesehatan Ibu dan Anak (PWS-KIA). Jakarta: Depkes RI

Errol R. Norwitz dan John O. Schorge. 2007. Obstetrics and Gynaecology at a Glance. Jakarta: Erlangga

Hall Robert E. 2000. Petunjuk Medis Bagi Wanita Hamil. Jakarta: Pustaka Delapratasa Hanifa W. 2005. Ilmu Kebidanan, Edisi Ketiga. Jakarta: Yayasan Bina Pustaka Sarwono Prawiroharjo

Harry K. Gondo. 2010. Pro I Operasi Seksio Sesarea di SMF Obstetri \& Ginekologi RSUP Sanglah, Denpasar Bali Tahun 2001 dan 2006 , CDK. Vol. 37. No, 2 MaretApril 2010

I Putu Sudiyana. 20013. Insiden Preeklampsi Eklampsia di Rumah Sakit Umum Tarakan Kalimantan Timur - tahun 2000, CDK. No. 139, 15 Juni 2003

Ibrahim Christina S. 1996. Keperawatan Kebidanan Jilid II. Jakarta. Bhratara.

Jaringan Nasional Pelatihan Klinik Kesehatan Reproduksi (JNPK-KR). 2002. Buku Acuan Nasional Pelayanan Kesehatan Maternal dan Neonatal. Jakarta: JNPKKR-POGI, Yayasan Bina Pustaka Sarwono Prawirohardjo

F. Gary Cunningham. 2006. Obstetri Williams. Jakarta: EGC (Penerbit Buku Kedokteran) Martius Gerhard. 1997. Bedah Kebidanan Martius. Jakarta: EGC (Penerbit Buku Kedokteran)

Neville F. Hacker, 2001. Esensial Obstetri dan Ginekologi. Jakarta: EGC (Penerbit Buku Kedokteran)

Ns. Narwoto dan Wasnidar. 2007. Buku Saku Anemia Pada Ibu Hamil, Konsep dan Penatalaksanaan. Jakarta: Trans Info Media

Royston Erica, 1994. Pencegahan Kematian Ibu Hamil. Jakarta: Bina Rupa Aksara

Rustam Mochtar. 2014. Synopsis Obstetric Jilid I (Obstetri Fisiologi-Obstetri Patologi). Jakarta: Buku Kedokteran EGC (Penerbit Buku Kedokteran)

Rustam Mochtar, 1998. Synopsis Obstetric Jilid II (Obstetri Operatif-Obstetri Sosial). Jakarta: Buku Kedokteran EGC (Penerbit Buku Kedokteran)
Stanley Lamonshow, 2013. Sampel dalam Penelitian Kesehatan. Yogyakarta: Gaja Mada University Press

Sudigdo Sastroasmoro.2012. Dasar- Dasar Metodologi Penelitian Klinis. Jakarta: Sagung Seto

Sugiono. 2014. Statistik untuk Penelitian. Jakarta: EGC (Penerbit Buku Kedokteran)

Suharsimi Arikunto. 2006. Prosedur Penelitian Suatu Pendekatan Praktik. Jakarta: PT Asdi Mahasatya

Sulaiman Sastrawinata, dkk. 2013. Obstetri Patologi. Jakarta: EGC (Penerbit Buku Kedokteran)

Sutrisno dan Edward Kurnia, 2008, Fetal Distress (Gawat Janin). http://kbi.gemari.or.id/beritadetail.php?id=4 983, (diakses pada 28 Mei 2009)

Syaifuddin Ali Akhmad. 2008. Panduan Lengkap Kehamilan, Persalinan, dan Perawatan Bayi. Jogjakarta: DIGLOSSIA MEDIA

Syamsul Arifin Nasution, 2013. Gambar Penanganan Kasus Kedaruratan Obstetri Di RSU Tanjung Pura Kabupaten Langkat dan $R S U$ Kisaran Kabupaten Asahan. http://library.usu.ac.id/download/fk/obstetrisyamsul.pdf, (diakses pada 25 Maret 2010) Sylvia K. Djajamiharsa, 2001. Bunda \& Buah Hati. Jakarta:

Mochtar R. 2012. Sinopsis Obstetri Jilid I Edisi ke2. Jakarta : EGC

Winkjosastro, H. 2015. Ilmu Kebidanan. Jakarta : Yayasan Bina Pustaka Sarwono Prawirohardjo 